lines in the Debye-Scherrer photographs were identified as due to the dissolved salt. The effect of various concentrations of gold and platinum dissolved in boric anhydride and borax glasses was also investigated, and other studies relating to the electrical and magnetic properties of single crystals of molybdenite indicate that along the basal plane the conductivity is wholly electronic above $90^{\circ} \mathrm{C}$. Raman spectra studies have demonstrated the formation of associated molecules of ethylene dibromide and aliphatic ketones in the solid state. The spectra of di-n-propyl ketone shows no appreciable fluorescence at room temperature; but an intense fluorescence band at 4880-5100 A. has been observed in the solid state at $-170^{\circ} \mathrm{C}$. The absorption and fluorescence spectra of anthracene have also been studied from the temperature of liquid oxygen to $100^{\circ} \mathrm{C}$. Many of these investigations carried out under the auspices of the Association have been reported as

"Lettors to the Editors" in Nature.

\section{Amateur Astronomy in Czechoslovakia}

ZIENEK KopaI an article on this subject in Sky and Telepe of July, in which he discusses the develop pents amateur astronomy in Czechoslovalkia since its $/$ ginnings in the second half of the nineteenth cespry. A large portion of the article is devoted to a survey of the careers of Josef and Jan Fric who, late in the last century, were among the first in Central Europe to photograph celestial objects systematically. The Ondrejov Observatory, on a hill about 1,700 ft. above sea-level and thirty miles south-east of Praha, was erected by Josef Fric as a memorial to his younger brother Jan, who died in 1897. It is interesting to know that one dome of the Observatory houses an 8-in. refractor, the lens of which was made nearly a century ago by the then unknown amateur optician, Alvan Clark. The Rev. W. R. Dawes, the well-known British amateur astronomer, purchased the lens from Clark, and after his death it was purchased by Prof. Safarik and eventually reached Praha. After the death of Safarik it came into the possession of the Fric brothers and was later mounted at Ondrejov. In 1917, the increase of astronomers in the country justified the founding of an astronomical society in Praha, and in 1928 the Czechoslovak Astronomical Society erected its own Observatory at Petrin Hill overlooking Praha. At present the membership numbers more than 2,400, and as there are only about eleven million Czechoslovaks living in Central Europe, this is probably the highest percentage of amateur astronomers in any country in the world. The article describes the activities of the Socioty at length, and forms very useful reading for those who are interested in the work of the amateur astronomer.

\section{Academy of Sciences of the U.S.S.R. : Design for New Buildings}

AcCordis to the Soviet News, work began immediately after the War on the new headquarters in Moscow of the Academy of Sciences of the U.S.S.R. The gligns were executed by the Russian architect Alexey Shchusev. A single building will house the Academy's general council, all its administrative offices, a central library for $6,000,000$ volumes, and ten institutes studying the humanities. It will be erected on the right bank of the Moscow River, opposite Gorky Park and next to the Crimea Bridge. The site has an area of more than 200,000 square yards, and the main façade will be 300 yards in length. The design provides for a central building with a tower at each end, and two side blocks with semicircular entrances. 'The seven-storied central building, $132 \mathrm{ft}$. high, will stand upon a five-floor basement, from which a broad staircase leads down to the river. In the centre there will be an eightcolumned portico $80 \mathrm{ft}$. high, supporting four pairs of Corinthian columns surmounted by a hexagonal dome. To the left of the portico will rise a 260 -ft. pierced tower. The main façade will be faced with natural stone. The building will stand in a large park in which eventually the Museum of the History of the Earth and the Museum of the History of Life will be built.

\section{British Archæology in Greece 51:}

Thоugl the Brits School of Archrology in Greece was necfistifly closed during the GermanItalian occupatipn, il was possible to publish during the wan ye $n$ two of its Annuals, representing the studies formex students. Volume 40, for 1940-45, nowisued (London: Macmillan and Co., Ltd. 2 g. 1 s.), contains obituaries of former students who lost their lives in the War; studies of miniature panathenaic vases by Prof. J. D. Beazley, of some provincial black-ware workshops by Mrs. A. D. Ure, and of inscriptions from Beroea by J. M. R. Cormack; an archæological survey of the classical antiquities of Chios by D. W. S. Hunt ; and a full publication by Sir John Myres of excavations in Cyprus under. taken for the Cyprus Museum, including a sanctuary site at Lefkóniko, settlement sites at Enkomi, Lampousa, and Larnaca, and a rich bronze-age cemetery at Lapithos ; with notes on the 'black stone' on the site of the famous temple at Paphos (which may be the actual cult-object), on the dates and origins of Cyprioti sculpture, and on the 'rising from the sea' of Aphrodite, a remarkable natural incident, resulting from the collision of incoming and reflected waves in certain winds on a steep beach, immediately in front of the Paphian. Temple.

With the restoration of more normal conditions in Greece, the British School has resumed some of its former activities. The buildings and library in Athens are unharmed; the Palace site and hostel at Knossos very little damaged; but excavation is suspended until the end of 1947, through the disorganisation of the Greek Department of Antiquities.

\section{Verticillium Disease of the Mushroom}

A USEFUL pamphy "entitled "Verticillium" on Mushrooms" las lands Gapup Aublications (Yaxley, Peterborough, 55 pd 1946. 68. net). Fred C. Atkins, honorary secretary of the Mushroom Growers' Association, reviews the history of the disease, its symptoms and control. Verticillium Malthousei is the causal fungus; it may be soil-borne, or carried by flies. The best method of control appears to be fumigation of mushroom houses by formalin vapour generated by mixing potassium permanganate and 40 per cent formaldehyde. An appendix contains extracts from "Control of Mushroom Diseases and Weed Fungi" by W. S. Beach (Bull. 35l, Pa. Agric. Exp. Sta., 1937). Infection by Verticillium is favoured by high relative humidity, and an additional measure of control lies in spraying a diseased area of the bed, after removal of the good mushrooms, with Bordeaux mixture. A further appendix is a reprint of the original paper by 